\title{
Biochemical and structural features of diverse bacterial glucuronoyl esterases facilitating recalcitrant biomass conversion
}

Jenny Arnling Bååth ${ }^{1 \dagger}$, Scott Mazurkewich ${ }^{1 \dagger}$, Rasmus Meland Knudsen², Jens-Christian Navarro Poulsen ${ }^{2}$, Lisbeth Olsson', Leila Lo Leggio ${ }^{2}$ and Johan Larsbrink ${ }^{1 *}$ (i)

\begin{abstract}
Background: Lignocellulose is highly recalcitrant to enzymatic deconstruction, where the recalcitrance primarily results from chemical linkages between lignin and carbohydrates. Glucuronoyl esterases (GEs) from carbohydrate esterase family 15 (CE15) have been suggested to play key roles in reducing lignocellulose recalcitrance by cleaving covalent ester bonds found between lignin and glucuronoxylan. However, only a limited number of GEs have been biochemically characterized and structurally determined to date, limiting our understanding of these enzymes and their potential exploration.

Results: Ten CE15 enzymes from three bacterial species, sharing as little as 20\% sequence identity, were characterized on a range of model substrates; two protein structures were solved, and insights into their regulation and biological roles were gained through gene expression analysis and enzymatic assays on complex biomass. Several enzymes with higher catalytic efficiencies on a wider range of model substrates than previously characterized fungal GEs were identified. Similarities and differences regarding substrate specificity between the investigated GEs were observed and putatively linked to their positioning in the CE15 phylogenetic tree. The bacterial GEs were able to utilize substrates lacking 4-OH methyl substitutions, known to be important for fungal enzymes. In addition, certain bacterial GEs were able to efficiently cleave esters of galacturonate, a functionality not previously described within the family. The two solved structures revealed similar overall folds to known structures, but also indicated active site regions allowing for more promiscuous substrate specificities. The gene expression analysis demonstrated that bacterial GEencoding genes were differentially expressed as response to different carbon sources. Further, improved enzymatic saccharification of milled corn cob by a commercial lignocellulolytic enzyme cocktail when supplemented with GEs showcased their synergistic potential with other enzyme types on native biomass.

Conclusions: Bacterial GEs exhibit much larger diversity than fungal counterparts. In this study, we significantly expanded the existing knowledge on CE15 with the in-depth characterization of ten bacterial GEs broadly spanning the phylogenetic tree, and also presented two novel enzyme structures. Variations in transcriptional responses of CE15encoding genes under different growth conditions suggest nonredundant functions for enzymes found in species with multiple CE15 genes and further illuminate the importance of GEs in native lignin-carbohydrate disassembly.
\end{abstract}

Keywords: Glucuronoyl esterase, Carbohydrate esterase, CE15, Carbohydrate-active enzyme, Biomass conversion, Lignin-carbohydrate complexes, Xylan

*Correspondence: johan.larsbrink@chalmers.se

†Jenny Arnling Bååth and Scott Mazurkewich contributed equally to this

work

${ }^{1}$ Wallenberg Wood Science Center, Division of Industrial Biotechnology,

Department of Biology and Biological Engineering, Chalmers University

of Technology, Gothenburg, Sweden

Full list of author information is available at the end of the article

(c) The Author(s) 2018. This article is distributed under the terms of the Creative Commons Attribution 4.0 International License (http://creativecommons.org/licenses/by/4.0/), which permits unrestricted use, distribution, and reproduction in any medium, provided you give appropriate credit to the original author(s) and the source, provide a link to the Creative Commons license, and indicate if changes were made. The Creative Commons Public Domain Dedication waiver (http://creativecommons.org/ publicdomain/zero/1.0/) applies to the data made available in this article, unless otherwise stated. 


\section{Background}

Deconstruction of the plant cell wall represents a significant challenge for microorganisms as the network of interlinked cellulose fibers, hemicelluloses, and lignin is highly recalcitrant to enzymatic attack. A feature of the plant cell wall that adds to its recalcitrance, but rather poorly characterized and understood, is the presence of covalent bonds between polysaccharides and lignin, the so-called lignin-carbohydrate complexes (LCCs) [1]. Three types of covalent LCC bonds have been identified: ester, ether, and glycosidic. Of these, enzymatic cleavage has to date only been proposed for the LC ester bonds, found between 4-O-methyl-glucuronoyl moieties of xylan and the alcohol moieties of lignin (Fig. 1a). The enzymes proposed to cleave these are glucuronoyl esterases (GEs), found in carbohydrate esterase family 15 (CE15) in the carbohydrate-active enzymes database (CAZy; http:// www.cazy.org; [2]). Since the characterization of the first
GE from Schizophyllum commune [3, 4], CE15 members from a multitude of biomass-degrading microorganisms have been identified, exhibiting as low as $15 \%$ sequence identity [5]. Despite the proposed importance of CE15 enzymes in LCC cleavage, only a handful of GEs have been biochemically characterized, and only three enzymes have been structurally characterized.

To date, 11 fungal $[3,6-15]$ and 2 bacterial GEs have been biochemically characterized $[16,17]$ using alkyl and alkyl aryl alcohol esters of 4-O-methyl glucuronic acid of varying complexity. An equatorial configuration of the C4 hydroxyl moiety has been proposed to be important for GE activity as fungal GEs have been reported to exclusively attack esters of D-glucuronic acid (GlcA) and not D-galacturonic acid (GalA) [6, 8]. Furthermore, studies of fungal GEs indicate that methylation of the $\mathrm{C} 4$ hydroxyl moiety is crucial for enzymatic activity. The two bacterial GEs described to date

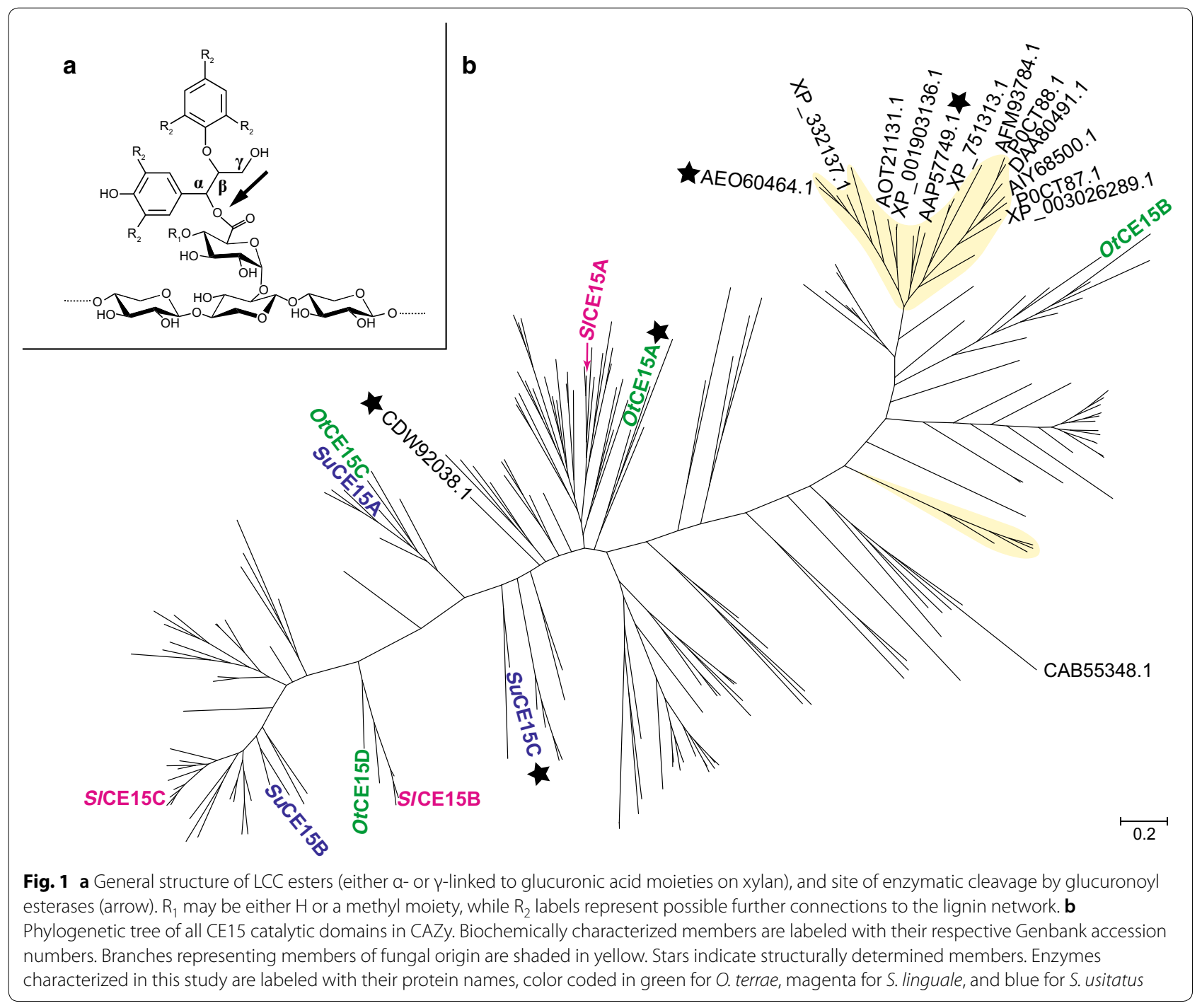


exhibit broader substrate specificities than studied fungal enzymes, with acetyl esterase activity detected on a variety of substrates [17, 18]. Regarding activity on native lignocellulosic material, the recent investigation of AaGE1 from the fungus Acremonium alcalophilum was the first report showing direct enzymatic LC ester cleavage of wood-extracted LCC fractions [19]. The role(s) of GEs on lignocellulose degradation has further been implied by somewhat improved saccharification of corn fiber by addition of fungal GEs to commercial hydrolytic enzyme cocktails [20], and recently the fungal Cerrena unicolor $\mathrm{CuGE}$ was shown to release aldouronic acid products and act synergistically with a GH10 endo-xylanase on birchwood lignin precipitates [21].

Two fungal and one bacterial CE15 protein structures have been solved: Cip2 from Hypocrea jecorina (PDB: 3pic), StGE2 from Myceliophtora thermophila (PDB: 4g4g), and MZ0003, a bacterial CE15 cloned from a marine metagenomic library (PDB: 6ehn) [22-24]. The enzymes are $\alpha / \beta$-hydrolases with a catalytic triad typical of esterases. MZ0003 is distinct from the fungal structures, by having a deeper substrate binding pocket, and the residue providing the acidic functionality of the catalytic triad is found on a different loop. The only CE15 structure with a ligand is an active site mutant of StGE2, co-crystallized with the methyl ester of 4-O-methyl glucuronoate (PDB: 4g4j) [23].

Interestingly, many microorganisms encode several CE15 proteins, indicating potential differences in both substrate specificities and physiological functions. To gain insights into the biological roles of CE15 enzymes that are diverse in primary sequence, we performed detailed analyses of ten unique CE15 members from three bacterial species. The targets, exhibiting sequence identities as low as $25 \%$, were biochemically characterized using a range of model substrates, and the threedimensional structures were solved for two of the enzymes. We investigated the regulation of CE15 gene expression in response to different carbon sources for one of the species, and furthermore demonstrated the potential of GEs to enhance hydrolysis of native (nonpretreated) lignocellulosic material, by supplementing a commercial hydrolytic enzyme cocktail with GEs, which resulted in significantly improved saccharification. These findings provide novel insights into the diversity, substrate specificities, structural differences, and activity on biomass-derived substrates of bacterial members across the CE15 family.

\section{Results}

\section{Phylogenetic analysis}

Since its creation over a decade ago, the CE15 family remains largely unexplored, with most studies having focused on fungal enzymes, despite a much greater number of bacterial members. To investigate the sequence diversity of the family, a phylogenetic tree of all CE15 catalytic domains was constructed (Fig. 1b; Additional file 1: Figure S1). CE15 is currently a small family (239 entries in CAZy, July 2018) and the phylogeny illustrates a high sequence divergence with many deeply rooted lineages. The tree revealed apparent separations of fungal and bacterial members, with fungal enzymes clustering into a major and a minor clade. All hitherto-characterized fungal enzymes fall into the major clade, which is also most dissimilar to the majority of bacterial members regarding primary protein structure. Being a small family with members exhibiting high sequence diversity (as low as $25 \%$ identity), branching in sections of the tree could, however, not be strongly supported by bootstrap analysis (Additional file 1: Figure S1). The two previously partially characterized bacterial enzymes were found in the middle section of the tree, which leaves the majority of the tree completely unexplored. To explore the diversity of CE15, and possibly unravel new functionalities, ten bacterial enzymes spanning the phylogenetic tree were selected for in-depth studies. The targets were selected from three bacterial species from different habitats where active decomposition of plant biomass occurs, and which all encode multiple putative CE15 enzymes: Opitutus terrae (anaerobic, isolated from anoxic rice paddy soil, Italy; 4 enzymes [25]); Spirosoma linguale (aerobic, isolated from lab water bath, found globally in freshwater and soil environments; 3 enzymes [26]), and Solibacter usitatus (aerobic, pasture soil, Australia; 3 enzymes [27]). The genomes of the selected organisms do not encode additional CE15 enzymes, and further, all targets were distinctly different in primary sequence (Additional file 1: Table S1). Why certain species encode multiple distinct CE15 enzymes (to date, $\leq 4$ CE15 genes in a single genome [2]) is unclear, and the choice of targets enabled analysis of potential different biological roles.

\section{Biochemical characterization and substrate specificity}

The activities of the ten $O$. terrae, S. linguale, and $S$. usitatus CE15 enzymes were assayed on a range of substrates, and kinetic parameters determined where possible (Table 1; Additional file 1: Table S2, Figure S2). All enzymes rapidly cleaved the ester bond in benzyl glucuronoate (BnzGlcA), which was used to determine their respective $\mathrm{pH}$ dependencies. The $S$. linguale enzymes differed from the $O$. terrae and $S$. usitatus enzymes by exhibiting lower $\mathrm{pH}$ optima (pH 5.5-6.5 vs. 7-8.5) (Additional file 1: Figure S3). Three of the enzymes, OtCE15D, $\mathrm{SuCE15A} \& \mathrm{C}$, exhibited exceptionally high catalytic efficiencies (in the $10^{4} \mathrm{~s}^{-1} \mathrm{M}^{-1}$ range) on BnzGlcA (Table 1), which is 10 to 100 -fold higher than reported for fungal 
Table 1 Catalytic efficiencies of the investigated CE15 enzymes on model substrates

\begin{tabular}{|c|c|c|c|c|c|}
\hline \multirow[t]{2}{*}{ Enzyme/substrate } & \multicolumn{5}{|c|}{$k_{\text {cat }} / K_{\mathrm{m}}\left(\mathrm{s}^{-1} \mathrm{M}^{-1}\right)^{\mathrm{a}}$} \\
\hline & BnzGlcA & AllylGIcA & MeGlcA & MeGalA & $p N p-A c$ \\
\hline OtCE15A & $4.64 \times 10^{3}$ & $8.80 \times 10^{3}$ & $6.85 \times 10^{3}$ & $4.85 \times 10^{3}$ & $3.23 \times 10^{1}$ \\
\hline OtCE15B & $1.86 \times 10^{1}$ & 2.82 & 1.14 & 8.68 & 2.56 \\
\hline OtCE15C & $1.16 \times 10^{4}$ & $2.49 \times 10^{3}$ & $8.98 \times 10^{2}$ & $1.19 \times 10^{3}$ & $3.97 \times 10^{1}$ \\
\hline OtCE15D & $1.11 \times 10^{4}$ & $3.45 \times 10^{3}$ & $5.19 \times 10^{2}$ & $1.95 \times 10^{-6}$ & 9.51 \\
\hline SICE15A & $1.88 \times 10^{3}$ & $1.00 \times 10^{3}$ & $1.55 \times 10^{3}$ & $3.82 \times 10^{1}$ & $3.09 \times 10^{1}$ \\
\hline S/CE15B & $2.60 \times 10^{3}$ & $9.08 \times 10^{2}$ & $4.57 \times 10^{2}$ & $3.66 \times 10^{-7}$ & $N D^{b}$ \\
\hline SICE15C & $9.69 \times 10^{1}$ & $1.11 \times 10^{2}$ & $1.03 \times 10^{2}$ & $3.73 \times 10^{-6}$ & $N D^{b}$ \\
\hline SUCE15A & $2.20 \times 10^{4}$ & $5.47 \times 10^{3}$ & $2.32 \times 10^{3}$ & $1.62 \times 10^{3}$ & 5.09 \\
\hline SUCE15B & $1.49 \times 10^{3}$ & $3.65 \times 10^{2}$ & $6.00 \times 10^{-2}$ & $9.00 \times 10^{-3}$ & $1.82 \times 10^{1}$ \\
\hline SUCE15C & $2.27 \times 10^{4}$ & $1.57 \times 10^{4}$ & $1.66 \times 10^{4}$ & $1.59 \times 10^{3}$ & $1.09 \times 10^{1}$ \\
\hline
\end{tabular}

Benzyl (Bnz), allyl (Allyl) and methyl (Me) esters of glucuronoate (GlcA) and galacturonoate (GalA), and 4-nitrophenol acetate ( $p$ NP-Ac)

a SEM of duplicate measurements are presented in Additional files 1

b Not determined due to activities below the detection limit

GEs [9, 13, 15, 28]. SuCE15C also exhibited high catalytic efficiency on allyl- and methyl-substituted glucuronoate esters (AllylGlcA and MeGlcA, respectively). No kinetic parameters have previously been reported for bacterial GEs which limits direct comparisons.

$K_{\mathrm{m}}$ values for fungal GEs acting on BnzGlcA have consistently been reported in the millimolar range, albeit with large variations $(\sim 2-80 \mathrm{mM})$. The bacterial CE15 enzymes investigated here displayed $K_{\mathrm{m}}$ values at a much lower and narrow range, with four enzymes (OtCE15C \& D, SlCE15B, and SuCE15A) reaching sub-millimolar values (0.4-0.6 mM; Additional file 1: Table S2). Submillimolar $K_{\mathrm{m}}$ values have for fungal CE15 members only been observed for few cases on 4-O-methylated esters of glucuronic acid $[6,8,29]$; substrates with this substitution are not commercially available. The remarkably low $K_{\mathrm{m}}$ values of the bacterial enzymes indicate that the 4-O-methyl substitution on BnzGlcA is not a strict requirement for all CE15 enzymes which possibly reflects potential variability in biomass substrate structure.

Most of the enzyme targets exhibited minimal discrimination between the ester substituents on glucuronate moieties (benzyl, allyl, or methyl; Additional file 1: Figure S2, Table S2). However, several enzymes (Fig. 1b), i.e., OtCE15C \& D, SlCE15B, and SuCE15A, displayed tenfold increases in $K_{\mathrm{m}}$ for AllylGlcA and MeGlcA compared to BnzGlcA. OtCE15A \& C, and SuCE15A, further exhibited little to no discrimination between methyl esters of glucuronoate versus galacturonoate (MeGalA; Table 1; Additional file 1: Table S2), contrasting especially $O t C E 15 D$ and SlCE15B \& C, which exhibited $10^{7-9}$-fold lower $k_{\text {cat }} / K_{\mathrm{m}}$ values for MeGalA. Enzymes with comparable or higher activity on MeGalA versus MeGlcA were assayed for pectin methyl esterase activity, but no activity (MeOH release) could be detected.
Acetyl esterase activity, mainly on 4-nitrophenyl acetate ( $p$ NP-Ac), has been reported with MZ0003 [17]. The CE15 enzymes investigated here displayed only trace activity on $p$ NP-Ac, with $\sim 1000$-fold lower $k_{\text {cat }} / K_{\mathrm{m}}$ values compared to MZ0003 (Table 1). Acetyl xylan esterase activity was investigated on 1,2,3,4-tetra-O-acetyl- $\beta$-Dxylopyranose (TetAcXyl) and biomass (ball milled corn cob and Japanese beech) using the four $O$. terrae enzymes which apparently span the phylogenetic tree. The $k_{\mathrm{cat}} / K_{\mathrm{m}}$ values of the enzymes were as low or lower on TetAcXyl as on $p$ NP-Ac (Additional file 1: Table S2), and no liberated acetate was detected after prolonged incubation of the enzymes with biomass, indicating that the enzymes are GEs without significant acetyl esterase activity.

\section{Structural determinations Overall structure}

As structural information regarding CE15 enzymes is sparse, with only two fungal and one bacterial structure solved to date [22-24], structural determination of all the CE15 members investigated here was pursued using X-ray crystallography. Structures for two CE15 enzymes were solved by SAD phasing (seleno-L-methionine for $\mathrm{SuCE15C}$, PDB ID 6gu8; and gold-derivatized $0 t \mathrm{CE} 15 \mathrm{~A}, \mathrm{PDB}$ ID 6grw) and subsequent molecular replacement (native $S u C E 15 \mathrm{C}$ and OtCE15A,; PDB ID 6gry and 6gs0, respectively).

The overall folds of OtCE15A and SuCE15C conform to the $\alpha / \beta$-hydrolase fold of the previously solved CE15 structures $[\mathrm{C} \alpha$ root mean square deviation of $2.2 \AA$ to 3pic and 4g4g over 304 residues; and $1.4 \AA$ to 6 ehn over 372 residues for OtCE15A; $2.6 \AA$ to 3 pic; $2.7 \AA$ to $4 \mathrm{~g} 4 \mathrm{~g}$ over 305 residues; and $2.3 \AA$ to 6 ehn over 377 residues for $\mathrm{SuCE} 15 \mathrm{C}(30)$ ], consisting of a three-layer $\alpha \beta \alpha$ sandwich with a solvent-exposed cleft comprising the active 
site and catalytic residues (Fig. 2). A single molecule was found in the asymmetric units of both OtCE15A and $\mathrm{SuCE} 15 \mathrm{C}$, and crystal contact analysis with PISA [30] supported a monomeric state in solution consistent with gel filtration analysis (data not shown).

\section{Comparison of overall structure}

Similar to the recently solved structure of MZ0003, both $O t C E 15 \mathrm{~A}$ and $\mathrm{SuCE} 15 \mathrm{C}$ differ from the fungal structures by the presence of 3 inserted regions (Reg1-3; Fig. 2c, d). Reg1 comprises 12 residues which extend $\beta 1, \beta 2$, and the loop between the strands. The sequence identity between the MZ0003, OtCE15A, and SuCE15C in this region is high $(\geq 80 \%)$ and the loop region packs against a portion of Reg2. Like MZ0003, Reg2 in OtCE15A and SuCE15C comprises $40-45$ residues originating from $\beta 4$ and contains a few short helical segments and, in the case of SuCE15C, two $\beta$ strands which form a slightly misaligned antiparallel sheet. Reg2 packs against the face of the main $\beta$-sheet, extends across an $\alpha$-helix ( $\alpha 5$ in OtCE15A and $\alpha 4$ in $\mathrm{SuCE} 15 \mathrm{C}$ ), and packs against Reg1 forming a contiguous unit between the two regions. Reg3 is a 15-residue hydrophilic loop found between, and packing against, the last $\beta$-strand of the main sheet and an $\alpha$-helix $\left(\alpha_{9}\right.$ and $\alpha_{8}$ in $O t C E 15 \mathrm{~A}$ and $\mathrm{SuCE} 15 \mathrm{C}$, respectively) (Fig. 2a, b).

\section{Comparison of active site pockets}

The catalytic triad (Ser/His/Glu) and most of the residues shown to interact with the glucuronoate ester moiety in the previously solved fungal StGE2 structure [23] are conserved in OtCE15A, SuCE15C, and the previously determined MZ0003 (Fig. 3A-C; Additional file 1: Figure S4).

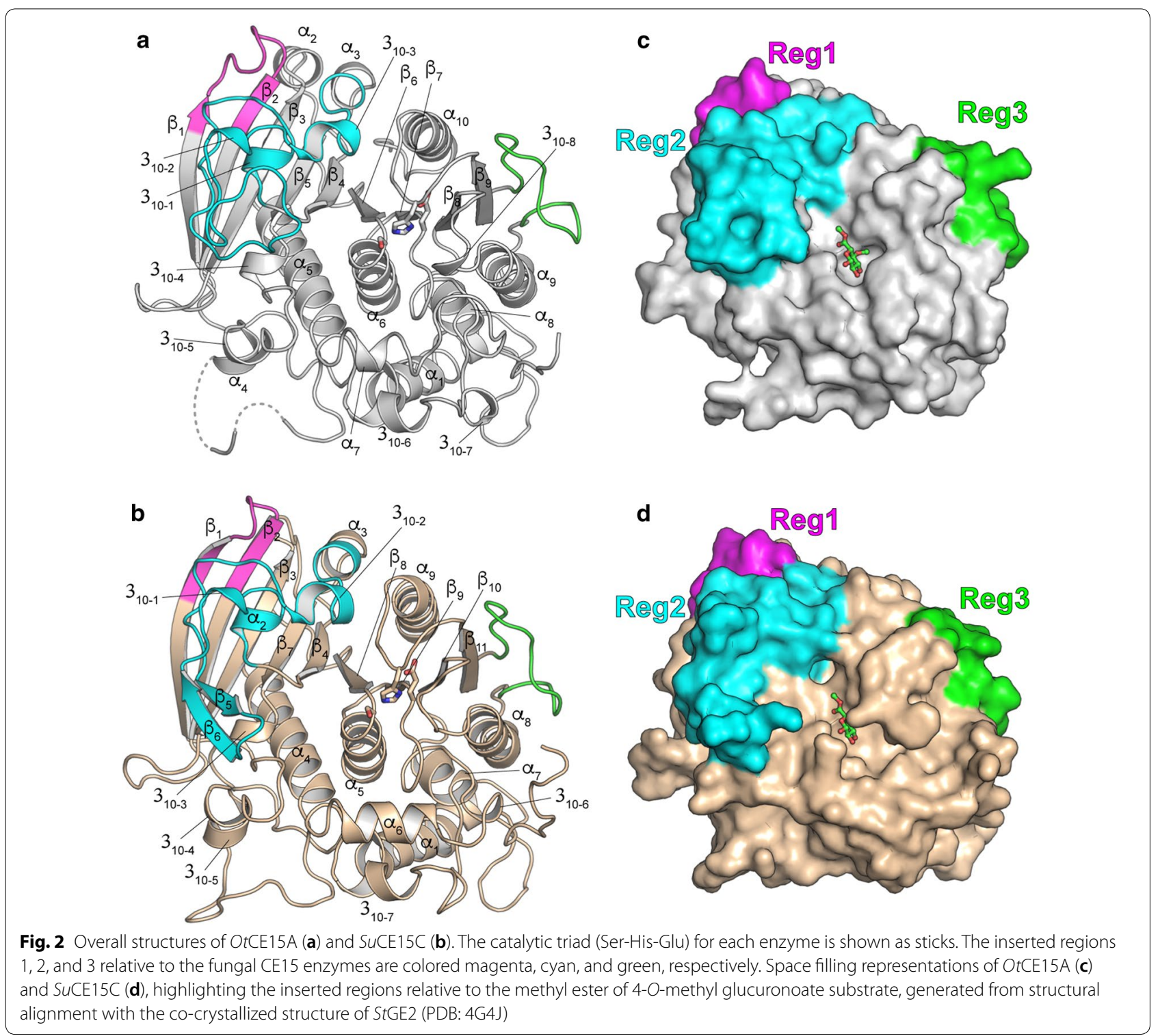


The tryptophan residue in StGE2 (Trp310) found hydrogen bonding to the 2-OH of the ligand is conserved in the bacterial structures (Trp358 in OtCE15A, Trp348 in $\mathrm{SuCE15C}$, and Trp334 in MZ003), whereas Glu267 in StGE2 which hydrogen bonds with both 2-OH and the anomeric hydroxyl group (in $\beta$ configuration) is not conserved (Arg303 in SuCE15C, Val313 in OtCE15A, and Ser289 in MZ0003). Gln259 of StGE2 is observed hydrogen bonding with both the $2-\mathrm{OH}$ and $3-\mathrm{OH}$ moieties of the sugar ring, and the equivalently positioned residues (with respect to main chain) in $O t C E 15 \mathrm{~A}, \mathrm{SuCE} 15 \mathrm{C}$, and MZ0003 are Glu305, Glu295, and Glu281, respectively. However, in SuCE15C, the loop containing Glu295 is modeled with the acidic side chain rotated away from the active site, and instead Arg296 occupies the equivalent space.

An arginine in StGE2 (Arg214), found beside the catalytic serine (Ser213), is proposed to form the stabilizing oxyanion hole during catalysis through the interaction of the main chain amino group and the carbonyl of the co-crystallized 4-O-methyl glucuronoate $(3.4 \AA$ distance) [23]. An arginine is found at the same position in OtCE15A (Arg268), SuCE15C (Arg258), and MZ0003 (Arg244), and is conserved in all CE15 enzymes characterized to date (Additional file 1: Figure S5), except
OtCE15B. OtCE15B has a tyrosine in the equivalent position, and the markedly reduced catalytic activity of the enzyme versus other GEs may be a result of the Arg $\rightarrow \mathrm{Tyr}$ substitution (Table 1). Further analysis of StGE2 reveals that, in addition to the main chain amino group, the $N^{\eta 1}$ of the Arg214 guanidinium moiety is positioned close to the substrate carbonyl ( $3.5 \AA$ distance), which together with the sequence conservation and crippled activity of OtCE15B suggests an important role of the guanidinium functionality in catalytically competent CE15 members.

The lysine residue (Lys217) in StGE2, noted to interact with the 4-O-Me oxygen of the ligand is conserved in the bacterial structures (Lys271 in OtCE15A, Lys261 in $\mathrm{SuCE} 15 \mathrm{C}$, and Lys247 in MZ0003). A small hydrophobic patch in StGE2 (Ile308 and Leu311) possibly aids in positioning the 4-O-Me moiety (Fig. 3D), and in all fungal enzymes characterized to date, the leucine is conserved while various hydrophobic residues are found at the position of the isoleucine (Additional file 1: Figure S5). In the bacterial structures, small residues are found in the equivalent leucine position (Ala359 in OtCE15A, Ser349 in $\mathrm{SuCE} 15 \mathrm{C}$, and Ala335 in MZ0003) while an aspartate residue is found in the same position as the isoleucine (Asp356 in OtCE15A, Asp346 in SuCE15C, and Asp332

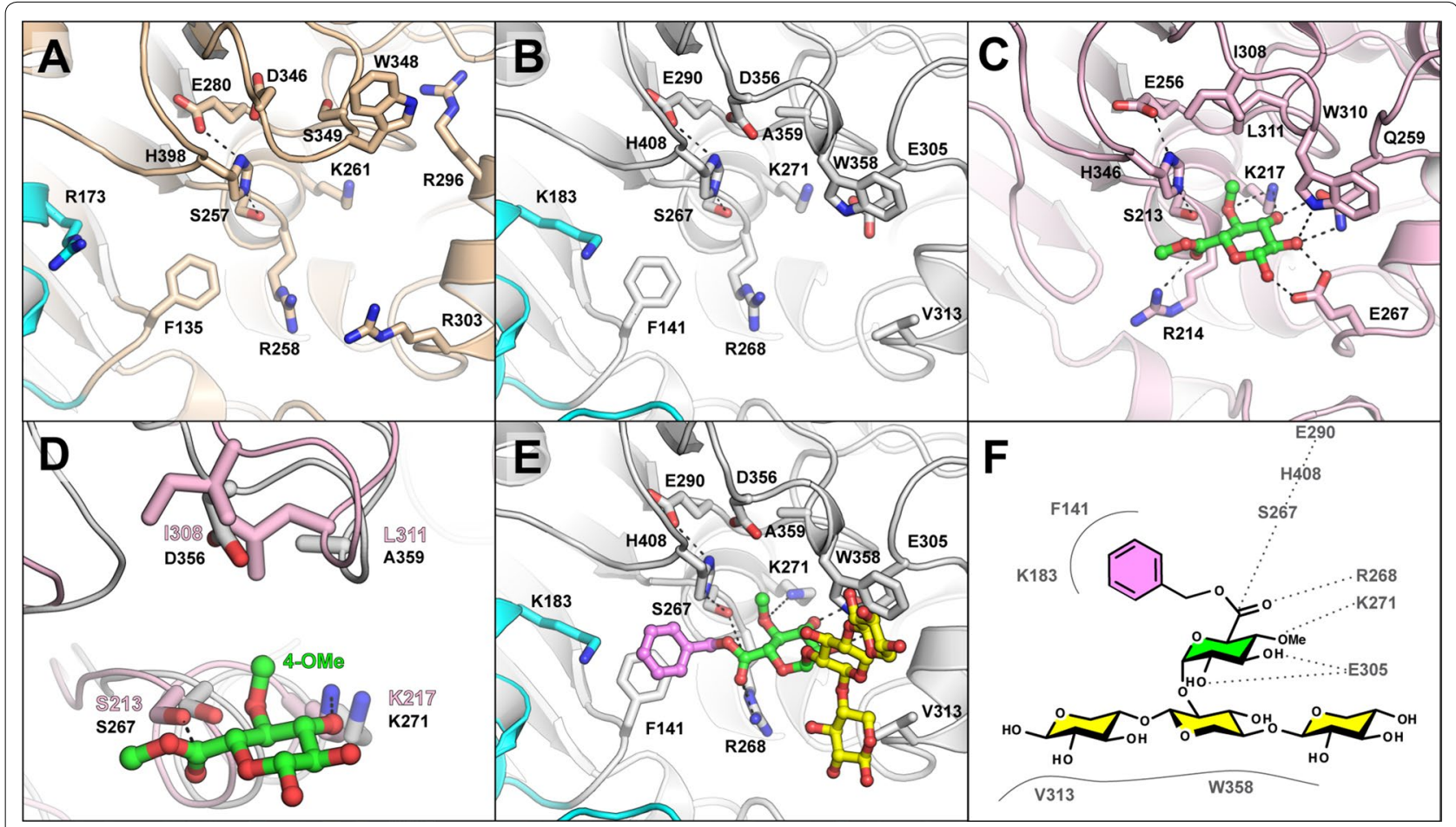

Fig. 3 Active site organization and docking simulation. Comparison of active site pockets of the SuCE15C (A), OtCE15A (B), and StGE2 (C). The methyl ester of 4-O-methyl glucuronoate co-crystallized with StGE2 is shown in green sticks. The region around the binding site of the 4-O-methyl substituent in StGE2 (pink) and OtCE15A (grey) highlights a common aspartate in bacterial structures that contrasts the hydrophobic pocket of fungal enzymes (D). Representative docking simulation of OtCE15A with a benzyl ester of 4-O-methyl-glucuronoxylotriose (E) with proposed interactions indicated $(\mathbf{F})$ 
in MZ0003) (Fig. 3D; Additional file 1: Figure S4). Of the bacterial enzymes characterized here, all but three contain a small residue and an aspartate in the aforementioned positions (Additional file 1: Figure S5). OtCE15B, closest to the fungal clades (Fig. 1), and the $S u C E 15 \mathrm{~B}$ and SlCE15C enzymes, furthermost from the fungal members, maintain the fungal leucine and hydrophobic residue pattern. The presence of an aspartate in this position likely affects binding of substrates containing 4-O-Me moieties and may facilitate binding to unmethylated substrates, such as the model substrates utilized here.

A small cleft within the pocket formed by Reg2 contains a conserved phenylalanine residue (Phe141 in OtCE15A, Phe135 in SuCE15C, and Phe117 in MZ0003) and a basic residue (Lys183 in OtCE15A, Arg173 in SuCE15C, and Arg160 in MZ0003) (Fig. 3A, B; Additional file 1: Figure S4). The phenylalanine side chain is located behind the catalytic serine and between the catalytic histidine and the conserved arginine. In StGE2, the methyl group of the co-crystallized ester projects toward this position, suggesting possible binding interactions with aromatic lignin substituents. Of the bacterial enzymes characterized here, all but two contain a phenylalanine at the same position, by primary sequence alignment, while the two others contain a phenylalanine close in primary sequence which may fulfill a similar functionality (Additional file 1: Figure S5).

\section{Docking simulations}

To investigate putative lignin- and xylan-binding sites in our solved structures, docking simulations of OtCE15A and $\mathrm{SuCE} 15 \mathrm{C}$ with a benzyl ester of 4-O-methyl-glucuronoxylotriose (glucuronoate $\alpha-1,2$ linked to the middle xylose residue) were performed. Several binding poses presumed compatible with catalytic activity were observed. Consistent among these was the placement of the benzyl moiety toward, and sometimes stacking on top of, the conserved bacterial phenylalanine of Reg2 (Fig. 3F). The cleft formed by Reg2 is larger than a benzyl moiety, and lined with hydrophilic residues, which could possibly accommodate and provide specificity for larger lignin fragments containing multiple hydroxyl groups. The positioning of the xylotriose portion of the ligand was more variable but consistently spanned an $\alpha$-helix ( $\alpha_{7}$ in OtCE15A and $\alpha_{6}$ in SuCE15C) and stacked against a tryptophan residue (Trp358 in OtCE15A and Trp348 in SuCE15C). This tryptophan is conserved among all the characterized CE15 members, and in both StGE2 and the docked structures is found hydrogen bonding the glucuronoate $2^{\prime}-\mathrm{OH}$ with its $\mathrm{N} \varepsilon$ atom (Additional file 1: Figure S5). The docking simulations suggest that CE15 members can accommodate and possibly bind xylose residues proximal to the glucuronic acid of either glucuronoxylan or smaller oligosaccharides.

Transcriptional analysis of S. linguale CE15-encoding genes Several microorganisms encode multiple CE15 members, but the biological reason for this is unknown. To assess whether transcriptional differences exist in bacteria that encode multiple CE15 genes, $S$. linguale (the single cultivable species of the three investigated) was grown on glucose, xylose, corn cob xylan, and milled corn cob biomass, and its transcription of CE15 genes was monitored by quantitative reverse transcription PCR (RT-qPCR) relative to the RNA polymerase sigma factor rpoD (Fig. 4a). While slce15b was constitutively expressed in all growth conditions, expression of slce15a was similar for glucose, xylose, and xylan, but increased twofold on milled corn cob, and slce15c showed a three to fourfold increase in response to any xylose-containing carbon source compared to glucose. The expression of the SlCE15A-, B-, and C-encoding genes are thus apparently regulated by different biological cues. Together with the biochemical data, this differential regulation indicates nonredundancy and different roles of the CE15 enzymes in the biology of S. linguale.

\section{CE15 enzymes enhance the hydrolysis of corn cob}

Cleavage of the ester linkages found in LCCs could aid enzymatic saccharification of biomass through selective de-coupling of lignin from polysaccharides. To investigate possible boosting of lignocellulose hydrolysis through bacterial GE action, selected CE15 enzymes were added to the cellulo- and hemicellulolytic cocktail Ultraflo $^{\circledR}$ during hydrolysis of ball milled corn cob (no further pretreatment was performed to limit disruption of the chemical structure). Corn cobs are abundant industrial waste streams, consisting chiefly of cellulose (47\% dry weight; $d w$ ), but are also rich in complex heteropolysaccharides (heteroxylans, $28 \% \mathrm{dw}$, and arabinan, 5\% dw) [31]. The GEs SlCE15A, SuCE15A or $\mathrm{SuCE} 15 \mathrm{C}$ were selected to supplement hydrolysis reactions based on their high activity on BnzGlcA at pH 5.5 (recommended for Ultraflo ${ }^{\circledR}$ ) together with their high long-term stabilities. Increased concentrations of glucose, xylose, and arabinose were observed in all GE-supplemented reactions (Fig. 4b). Released arabinose and xylose increased moderately (20-50\%), whereas the glucose concentration increased dramatically by $90-300 \%$. $\mathrm{SuCE} 15 \mathrm{C}$ was consistently the most efficient boosting enzyme, followed by SuCE15A and SlCE15A, somewhat reflecting their activity levels on BnzGlcA (Table 1; Additional file 1: Table S2). The increases of released monosaccharides strongly suggest an important role of CE15 enzymes in facilitating more efficient substrate access for a range of classical polysaccharide-degrading enzymes. 
a

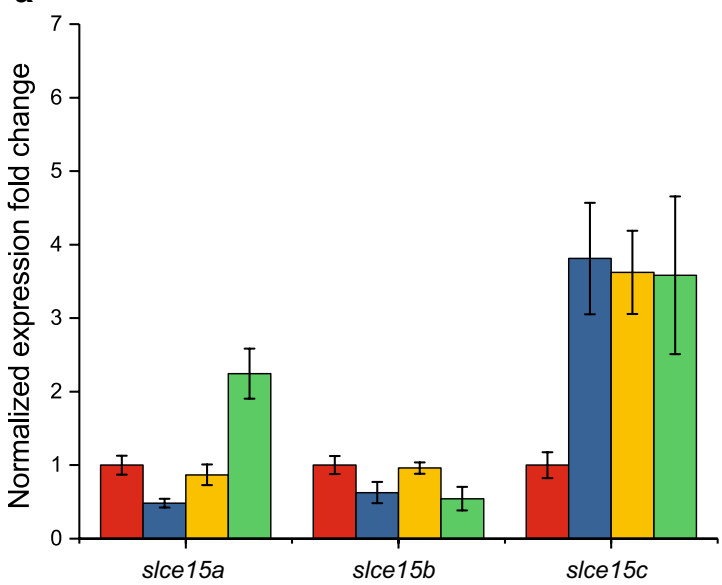

b

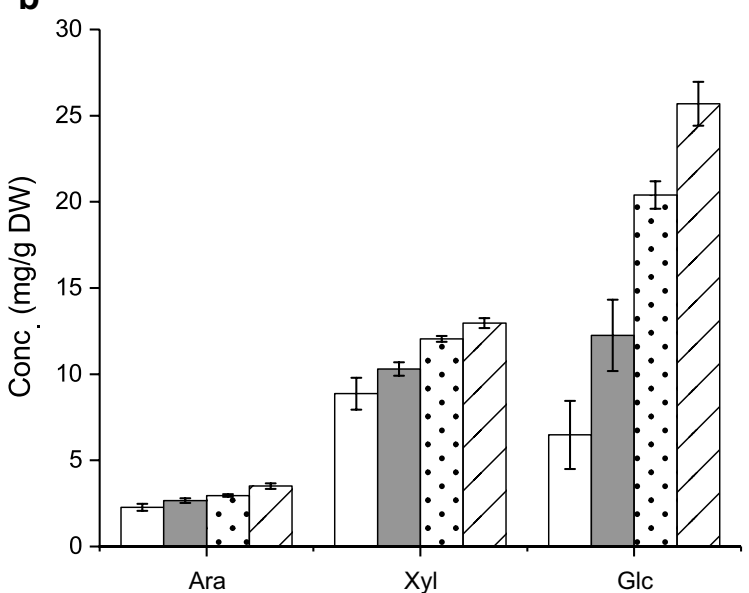

Fig. 4 a Change in CE15 gene expression (slce15A, slce15B, and slce15C) in S. linguale cells grown on xylose (blue), corn cob xylan (yellow), and corn cob biomass (green) normalized to growth on glucose (red). The RNA polymerase sigma factor rpoD (locus tag Slin_1987) served as reference gene. Error bars indicate the SEM of triplicate measurements. b Release of monosaccharides (arabinose, xylose, and glucose) after 24-h enzymatic hydrolysis of ball-milled corn cob using Ultraflo ${ }^{\circledR}$, without the addition of CE15 (white), or with the addition of SICE15A (gray), SUCE15A (dotted), or SUCE15C (striped). Error bars represent the SEM of triplicate measurements

\section{Discussion}

Glucuronoyl esterases have been suggested to play a crucial role in separating carbohydrates from lignin in lignocellulose. Direct evidence of the biological role(s) of these enzymes is still speculative, due to a lack of suitable analytical methods on native biomass and extracted LCCs. The ten bacterial enzymes investigated here have significantly higher catalytic efficiencies and wider substrate ranges on model substrates than previously characterized CE15 enzymes, suggesting abilities to act on diverse natural substrates. The similarities and differences in substrate specificities among the CE15 enzymes appeared to correspond to the enzymes' location in the phylogenetic tree, and the transcriptional analyses support the hypothesis of nonredundant roles of the gene copies within bacterial species encoding multiple CE15 enzymes.

Previous studies have demonstrated that fungal GEs have strict substrate specificities for glucuronoate esters and require methyl substitutions on the 4-OH of the glucuronoate for full activity $[9,15,32]$. Several bacterial enzymes seem to lack these constraints and display the highest recorded $k_{\text {cat }} / K_{\mathrm{m}}$ values of GEs to date on the BnzGlcA model substrate, lacking 4-OH methylation. Further, the majority of the studied bacterial enzymes had similar $K_{\mathrm{m}}$ values and high catalytic efficiencies on all GlcA ester substrates, regardless of the alcohol portion. Several did not discriminate between MeGlcA and MeGalA demonstrating that CE15 members are not restricted to act on GlcA-derived esters as previously claimed. The hydrophobic patch observed in fungal structures, which may support 4-O-Me positioning, is changed in many bacterial enzymes to a more open and hydrophilic region that may contribute to more promiscuous substrate specificities. However, comparison of the sequences and kinetics of all characterized enzymes in the present study does not completely correlate with this observation. In particular, OtCE15D and SlCE15B, possessing equivalent residues as $O t C E 15 \mathrm{~A}$ and $S u C E 15 \mathrm{C}$ in this region, were unable to be saturated with MeGalA, indicating that other determinants contribute to uronate discrimination.

The structural determinations of OtCE15A and SuCE15C reveal similar overall folds to previously determined CE15 structures, with closest structural similarity to the recently released bacterial structure of MZ0003 [22-24]. Of the three inserted regions found in the bacterial structures, Reg1 and Reg2 form a contiguous unit proximal to the active site, and sequence analysis suggests that, although with variation of length and sequence diversity, these inserted regions may be conserved among bacterial CE15 members. Catalytically competent docking poses consistently positioned the benzyl ring of glucuronoate esters near, or stacking with, a phenylalanine conserved among most bacterial CE15 members, suggesting a previously unidentified binding site for the (lignin-derived) alcohol moiety in LCC substrates. Several GEs, from both fungal and bacterial origins, have marked preferences for larger ester substituents, such as having improved kinetic parameters for BnzGlcA versus MeGlcA, which supports the hypothesis that molecular determinants to facilitate binding of larger lignin fragments exist within some GEs $[9,13]$. Due to the lack of larger ligands in 
CE15 structures, identification of residues providing specificity, or tolerance, to lignin fragments remains tentative. However, the large ridges inserted proximal to the active site in bacterial structures constitute putative lignin binding faces, which may be illuminated in future studies. Similarly, residues putatively conferring preference for the backbone of glucuronoxylan poly- or oligosaccharides have here been identified but require validation in future studies.

Not only did some of the investigated bacterial CE15 members show unprecedented catalytic efficiencies on model substrates, but improved saccharification of unpretreated biomass was observed for GE-supplemented commercial lignocellulolytic enzyme cocktails. LCC-cleaving activities may be particularly important in the initial stages of hydrolysis of intact biomass, where the GEs likely increase the accessibility of other glycolytic enzymes to polysaccharides in the complex plant cell wall matrix. In addition, a tight functional relationship between GEs and xylanases can be postulated, where GEs act either prior to, or in concert with, endo-xylanases to detach xylan from lignin, or release xylanase-generated xylooligosaccharides from lignin networks for further degradation into monosaccharides. In agreement with our study, recent work has reported a synergistic cooperation of a fungal GE and xylanases [21]. However, we also detected striking increases in glucose concentration in GE-enhanced reactions, indicating that not only xylanases, but a range of lignocellulolytic enzymes are aided by the GE action. In-depth understanding of the enzymatic cleavage of LCCs in native structures and enzyme cooperativity may be revealed by future enzyme synergy studies on complex plant biomass.

\section{Conclusion}

By structural and functional characterization, as well as gene expression analysis of a range of bacterial GEs spanning the CE15 phylogenetic tree, we have significantly expanded the existing knowledge on CE15 enzymes. Enzyme kinetic analyses of diverse bacterial CE15 members highlight common features as well as functional diversity. The boosting effects of bacterial GEs on biomass saccharification supports the proposed role of the enzymes to aid in reducing lignocellulose recalcitrance while variations in transcriptional responses of CE15encoding genes during different growth conditions suggests nonredundant functions for enzymes found in species with multiple CE15 genes, possibly indicating that biomass specificity exists within the CE15 family. Taken together, the results provide a foundation for further fundamental and applied research regarding microbial degradation of recalcitrant plant cell walls.

\section{Methods \\ Phylogenetic analysis}

The protein sequences of all CE15 members (214 entries) were downloaded from CAZy (Feb 2018) and used to construct the phylogenetic tree as described previously [33]. Briefly, the sequences were trimmed to comprise only catalytic domains, aligned using MUSCLE [34], and the tree computed using PHYML [35].

\section{Cloning, expression, and purification of bacterial CE15 genes}

The CE15 genes were amplified from genomic DNA of O. terrae DSM 11246, S. linguale DSM 74 and S. usitatus DSM 15142 (DSMZ, Germany) by PCR (primers in Additional file 1: Table S3), and the products cloned into modified pET-28a vectors (In-Fusion HD kit, Clontech Laboratories), containing $\mathrm{N}$-terminal $\mathrm{His}_{6}$ tags and TEV protease cleavage sites (generously provided by $\mathrm{N}$. Koropatkin, University of Michigan). The OtCE15 genes, $S l C E 15 \mathrm{~A}, \mathrm{SuCE} 15 \mathrm{~A}$ and $\mathrm{SuCE15C}$ were expressed in E. coli BL21(入DE3). OtCE15D was expressed in E. coli Rosetta2( $\lambda \mathrm{DE} 3$ ). SlCE15B and SlCE15C were coexpressed with translation elongation factor (tig) from pTf16 and $\mathrm{SuCE15B}$ with groES-groEL-tig from p6-Tf2 (Clontech Laboratories) to yield sufficient soluble protein.

Cells were grown in antibiotics-supplemented lysogeny broth (LB) at $37^{\circ} \mathrm{C}$ and $200 \mathrm{rpm}$ under shaking until attaining an $\mathrm{OD}_{600} \sim 0.5$ when expression was induced at by addition of isopropyl $\beta$-D-1-thiogalactopyranoside (IPTG) to a final concentration of $0.2 \mathrm{mM}$ and the cells incubated at $16{ }^{\circ} \mathrm{C}$ overnight. For confirming chaperone coexpression, chaperones were induced at an $\mathrm{OD}_{600} \sim 0.3$ by addition of $1 \mathrm{mg} / \mathrm{mL}$ L-arabinose (pTf16) or $10 \mathrm{ng} /$ $\mathrm{mL}$ tetracycline (p6-Tf2), followed by IPTG induction as described at $\mathrm{OD}_{600} \sim 0.5$. Cells were harvested by centrifugation $(5000 \times g 10 \mathrm{~min})$, resuspended in $20 \mathrm{mM}$ tris(hydroxymethyl)aminomethane (TRIS) buffer ( $\mathrm{pH} 8$ ) containing $250 \mathrm{mM} \mathrm{NaCl}, 5 \mu \mathrm{g} / \mathrm{mL}$ lysozyme, and $10 \mu \mathrm{g} /$ $\mathrm{mL}$ DNase, and disrupted by sonication. Cell debris was removed by centrifugation $(18,000 \times g, 10 \mathrm{~min})$, and proteins were purified using immobilized metal ion affinity chromatography on an ÄKTA system (GE healthcare) using $5 \mathrm{~mL}$ HisTrap ${ }^{\mathrm{TM}}$ Excel columns, with $50 \mathrm{mM}$ TRIS (pH 8), $250 \mathrm{mM} \mathrm{NaCl}$ as binding buffer, and one-step elution (binding buffer incl. $250 \mathrm{mM}$ imidazole), followed by dialysis into $50 \mathrm{mM}$ TRIS buffer (pH 8). OtCE15A and $\mathrm{SuCE} 15 \mathrm{C}$ were further purified by anion and cation exchange chromatography, respectively. Anion exchange was performed on a HiLoad ${ }^{\mathrm{TM}} 16 / 10$ Q Sepharose column (GE healthcare) with $50 \mathrm{mM}$ Tris (pH 8) as loading buffer and elution using a linear gradient to $1 \mathrm{M} \mathrm{NaCl}$. Cation exchange was performed on a HiLoad ${ }^{\mathrm{TM}} 16 / 10$ SP Sepharose column (GE healthcare) with $50 \mathrm{mM}$ sodium acetate 
(pH 5) as loading buffer and elution using a linear gradient to $1 \mathrm{M} \mathrm{NaCl}$.

\section{Enzyme assays}

Esterase-mediated uronic acid formation was monitored continuously using the K-URONIC kit (Megazyme, Ireland). Kinetic measurements were performed in 96-well plates using a FLUOstar Omega (BMG LABTECH, Germany) in $200 \mu \mathrm{L}$ reactions containing $50 \mathrm{mM}$ sodium phosphate, $2 \mu \mathrm{L}$ uronate dehydrogenase, and $16 \mu \mathrm{L} \mathrm{NAD}^{+}$. The buffer $\mathrm{pH}$ was at or close to the enzymes' respective $\mathrm{pH}$ optima, due to substrate instability at higher $\mathrm{pH}$, and where $>75 \%$ of maximal enzyme activity is maintained: $\mathrm{pH} 7.5$ for $O$. terrae and S. usitatus enzymes and $\mathrm{pH} 6.5$ for $\mathrm{S}$. linguale enzymes. The substrates BnzGlcA, AllylGlcA, MeGlcA, and MeGalA (Additional file 1: Figure S2) (Carbosynth, UK) were dissolved in 100\% dimethyl sulfoxide (DMSO); all reactions contained $\leq 10 \%$ DMSO. Kinetic assays were performed at least in duplicate at $25{ }^{\circ} \mathrm{C}$ using enough enzyme to ensure $\geq 2$-fold change in substrate turnover versus autohydrolysis rates. $\mathrm{pH}$-dependency profiles were generated with $2 \mathrm{mM} \mathrm{BnzGlcA}$ in a three-component buffer containing $25 \mathrm{mM}$ acetic acid, $25 \mathrm{mM} 2-(N$-morpholino) ethanesulfonic acid, and $50 \mathrm{mM}$ Tris $-\mathrm{HCl}$, covering $\mathrm{pH}$ 4.5-9.5 [36].

Acetyl esterase activity was assayed using 4-nitrophenyl acetate ( $p$ NP-Ac; Sigma Aldrich) and 1,2,3,4-tetra$O$-acetyl- $\beta$-D-xylopyranose (TetAcXyl; Carbosynth) (Additional file 1: Figure S2). $p$ NP release was detected at $\lambda_{405}$ and quantified using an extinction coefficient $18.7 \mathrm{mM}^{-1} \mathrm{~cm}^{-1}$. Acetate release from TetAcXyl were measured using the K-ACET kit (Megazyme). Pectin methyl esterase activity was assayed with poly-D-galacturonic acid methyl ester (Carbosynth) and citrus peel pectin (Sigma Aldrich) in reactions containing 0.2\% $(\mathrm{w} / \mathrm{v})$ pectin and $1 \mathrm{mg} / \mathrm{mL}$ CE15 enzyme. Reactions were collected at $30 \mathrm{~min}$ and $24 \mathrm{~h}$, filtered through a $10 \mathrm{kDa}$ Amicon spin filter, and methanol release through $\mathrm{NAD}^{+}$reduction using alcohol oxidase (Pichia pastoris, Sigma Aldrich) and formaldehyde dehydrogenase (Pseudomonas sp., Sigma) as previously described [37]. Nonlinear data were fitted to the Michaelis-Menten equation using GraphPad Prism (GraphPad, US). In nonsaturable cases, $k_{\text {cat }} / K_{\mathrm{m}}$ values were determined by linear regression.

\section{Quantification of $S$. linguale gene expression by qPCR} Spirosoma linguale DSM 74 was grown in media containing $0.5 \mathrm{~g} / \mathrm{L}$ peptone, $0.1 \mathrm{~g} / \mathrm{L}$ yeast extract, $15 \mathrm{mM} \mathrm{NaPO}_{4}$ $\mathrm{pH} 7.5,1 \mathrm{mM} \mathrm{MgSO}, 2 \mathrm{~mL} / \mathrm{L}$ trace metal solution [38] and $0.3 \%(\mathrm{w} / \mathrm{v})$ of carbon source (glucose, xylose, corn cob xylan or ball milled corn cob). Milled corn cob was sterilized with $70 \%$ ethanol, dried, and washed with water to remove soluble sugars before use. $4 \mathrm{~mL}$ cultures, inoculated to a $1 / 100$ dilution of an overgrown culture, were incubated at $30{ }^{\circ} \mathrm{C}$ with $200 \mathrm{rpm}$ shaking. At mid$\log$ phase $[20 \mathrm{~h}$ for monosaccharides and xylan, and $36 \mathrm{~h}$ for biomass (Additional file 1: Figure S6)], cells were harvested by centrifugation and resuspended in $1 \mathrm{~mL}$ of TRIzol (Invitrogen). To the Trizol-resuspended cell pellets, $200 \mu \mathrm{L}$ of chloroform was added, the reaction mixed, and the aqueous phase collected. RNA was precipitated in two volumes of isopropanol, washed twice with $500 \mu \mathrm{L}$ $70 \%$ ethanol, and resuspended in $50 \mu \mathrm{L}$ water. RNA samples were treated with Turbo DNase (Invitrogen), and cDNA was synthesized using RevertAid H Minus First Strand cDNA kit (ThermoFisher). qPCR was performed using primers, listed in Additional file 1: Table S3, and DyNAmo HS SYBR green (ThermoFisher) on a Stratagene MX3005P qPCR instrument (Agilent Technologies) using the following protocol: initial denaturation, 10 min at $95^{\circ} \mathrm{C}, 40$ cycles of 30 -s denaturation at $95^{\circ} \mathrm{C}$, and 30-s annealing/elongation at $60^{\circ} \mathrm{C}$. Specificity of the amplicons was determined by DNA duplex dissociation by $1 \mathrm{~min}$ at $95^{\circ} \mathrm{C}, 1 \mathrm{~min}$ at $55^{\circ} \mathrm{C}$, and $30 \mathrm{~s}$ at $95^{\circ} \mathrm{C}$. Three technical replicates of each biological triplicate were evaluated. Control reactions without a template gave no amplification, while controls with RNA instead of cDNA (RT-controls) had a $C_{\mathrm{t}}$ value $>5$ cycles higher than the $C_{\mathrm{t}}$ value of the target reaction, indicating low background levels of genomic DNA. The MxPro software (Agilent Technologies) was used to analyze the data. The RNA polymerase sigma factor $r p o D$ (Locus tag: Slin_1987) was used to normalize the data, based on predicted expression stability under the experimental conditions. Relative gene expression was quantified compared with growth on glucose using the $2^{-\Delta \Delta \mathrm{Ct}}$ method [39].

\section{GE-aided corn cob saccharification}

$2 \mathrm{~mL}$ hydrolysis reactions containing $0.5 \% \quad(\mathrm{w} / \mathrm{v})$ ball milled corncob, $0.1 \mathrm{mg}$ Ultraflo $^{\circledR}$ (Novozymes, Denmark)/g DW, without or supplemented with $175 \mathrm{nM}$ CE15 enzyme (SlCE15A, SuCE15A or SuCE15C) were performed in triplicate experiments, in $50 \mathrm{mM}$ sodium acetate (pH5.5) at $35{ }^{\circ} \mathrm{C}$ with $1000 \mathrm{rpm}$ mixing. Reactions were stopped after $10 \mathrm{~min}$ by heating at $95{ }^{\circ} \mathrm{C}$. A low concentration of Ultraflo ${ }^{\circledR}$ was chosen with to obtain limiting enzymatic hydrolysis conditions. No BnzGlcAcleaving activity was detected in Ultraflo ${ }^{\circledR}$. Released monosaccharides were monitored by high-performance anion exchange chromatography with pulsed amperometric detection on an ICS3000 system equipped with a $4 \times 250 \mathrm{~mm}$ Dionex Carbopac ${ }^{\mathrm{TM}}$ PA1 column with a $4 \times 50 \mathrm{~mm}$ guard column maintained at $30{ }^{\circ} \mathrm{C}$, (Dionex, Sunnyvale, CA, USA). $25 \mu \mathrm{L}$ samples were injected. The 
eluents were-A: Water; B: $300 \mathrm{mM}$ sodium hydroxide, and C: $100 \mathrm{mM}$ sodium hydroxide and $85 \mathrm{mM}$ sodium acetate. The samples were eluted isocratically with $100 \%$ eluent A for $40 \mathrm{~min}(1 \mathrm{~mL} / \mathrm{min})$ and detected with postcolumn addition of $0.5 \mathrm{~mL} / \mathrm{min}$ of solvent $\mathrm{B}$. Thereafter, a cleaning step with $40 \%$ eluent A and $60 \%$ eluent B was performed at $1 \mathrm{~mL} / \mathrm{min}$ for $10 \mathrm{~min}$. Peak analysis was performed using the Chromeleon software. Peaks were quantified against pure monosaccharide standards, and $10 \mathrm{mg} / \mathrm{L}$ fructose was added as an internal standard.

\section{Crystallization and data collection}

Tag-free $O t C E 15 \mathrm{~A}$ and $S u C E 15 \mathrm{C}$, generated by Histag cleavage by TEV protease and cleaned by passing through a $5 \mathrm{~mL}$ HisTrap ${ }^{\mathrm{TM}}$ Excel column, were screened for crystallization in MRC 2-drop crystallization plates (Molecular Dimensions) using an Oryx 8 Robot (Douglas Instrument). Sitting drops $(0.3 \mu \mathrm{L})$ were mixed with protein:reservoir volume ratios of $3: 1$ or $1: 1$ using $45 \mathrm{mg} / \mathrm{mL}$ of $O t C E 15 \mathrm{~A}$ or $20 \mathrm{mg} / \mathrm{mL}$ of $\mathrm{SuCE} 15 \mathrm{C}$, both in $20 \mathrm{mM}$ TRIS $\mathrm{pH}$ 8.0. Hits from Morpheus screens (Molecular Dimensions) were optimized, and final crystallization conditions were as follows: 0.09M NPS, $0.1 \mathrm{M}$ Buffer system 3, and 37.5\% v/v Precipitant mix 4 for OtCE15A; $0.12 \mathrm{M}$ Ethylene glycols, 0.1 M Buffer System 3, and 50\% v/v Precipitant Mix 1 for SuCE15C [40]. Datasets were collected on ID30B at the ESRF, Grenoble, France, and crystals of both proteins diffracted beyond $2 \AA$. The initial OtCE15A dataset collected belonged to space group P1 and diffracted to a resolution of $1.34 \AA$ but had limited completeness $(88.9 \%)$. Molecular replacement using the previously determined fungal CE15 structures as templates (25-30\% identity) was unsuccessful in each case, and collection of anomalous data was pursued. The pET-28a constructs were transformed into E. coli T7 Express Crystal (methionine auxotroph; $\mathrm{NEB}$ ), and the protein was expressed in minimal media containing seleno-L-methionine (SeMet) as per the supplier's recommendations (Molecular Dimensions). SeMet CE15 proteins, without the N-terminal His-tag removed, were screened for crystallization conditions, and only the $\mathrm{SuCE15C}$ SeMet-substituted protein yielded welldiffracting crystals. Crystals of the SuCE15C-SeMet were grown in 0.12 M Monosaccharides, 0.1 M Buffer System 3, 50\% v/v Precipitant Mix 1 [40]. Heavy-atom derivatization was trialed with native crystals of $O t C E 15 \mathrm{~A}$, and the final conditions achieved were obtained by adding $1.2 \mu \mathrm{L}$ of crystallization mother liquor containing $0.5 \mathrm{mM}$ of $\mathrm{KAu}(\mathrm{CN})_{2}$ to the drop containing crystals. Crystals of the OtCE15A used for derivatization were grown in $0.06 \mathrm{M}$ Divalents, 0.1 M Buffer system 1, 40\% v/v Precipitant mix 4 [40]. Derivatized crystals were soaked for $1 \mathrm{~h}$ before being flash-frozen in liquid nitrogen. Datasets of both the
$\mathrm{SuCE} 15 \mathrm{~A}-\mathrm{SeMet}$ and gold-derivatized $\mathrm{OtCE15A}$ were collected at beamline P11 of Petra III.

\section{Data processing and structure determination}

Diffraction data were processed with XDS [41] and structure solution completed in Phenix [42]. Autosol was used to solve the structure of the $\mathrm{SuCE15C-SeMet} \mathrm{which} \mathrm{was}$ subsequently used as a template for molecular replacement in Phaser to solve the native $\mathrm{SuCE} 15 \mathrm{C}$ structure $[42,43]$. Due to the better overall completeness, the $O t C E 15 \mathrm{~A}$ structure was first determined using the goldderivatized dataset, by molecular replacement in Phaser using the $\mathrm{SuCE} 15 \mathrm{C}$ as a template, and the model was subsequently used as a template for molecular replacement in Phaser to solve the native structure [42, 43]. Models of all the structures were initially built with Phenix AutoBuild [44], rebuilt in Coot [45], and further refined with Phenix Refine [46] in alternating cycles. OtCE15A structures were refined isotropically after checking that an anisotropic refinement scheme did not bring any significant improvement. Ligand compounds were added to the models in Coot, and the identity of the metals in the OtCE15A structure was validated using CheckMyMetal server [47]. Due to disorder and poor density, a small loop in the OtCE15A-Au (residues 221-223), two N-terminal residues in the OtCE15A-Native (Ala33 and Tyr34), the $\mathrm{C}$-terminal residue in OtCE15A-Au (Ala432), one residue in the SuCE15C-Native structure (Asp346), and one residue's side chain in the SuCE15C-SeMet (Trp327) were unable to be confidently modeled and were omitted. One loop in the OtCE15A-Native structure (residues 423429) was modeled in double conformation. All models had $\geq 96 \%$ residues' in the most favorable Ramachandran regions [48]. Additional file 1: Table S4 lists the data collection and final model refinement statistics.

\section{Alignments and docking simulations}

The multiple sequence alignment was completed with Clustal Omega [49] and the structural alignment was completed with DALI [50]. Both alignments were visualized with ESPRIPT [51] using the default percent equivalent coloring scheme. Docking simulations were completed with ROSIE using the atomic coordinates of OtCE15A, SuCE15C, and StGE2 (PDB accession: 4g4g) as the templates [52-55]. The 4-O-methyl-glucuronoxylotriose (glucuronoate $\alpha-1,2$ linked to the middle xylose residue) ligand was created in MarvinSketch (ChemAxon) and parameters in ROSIE were set to generate 500 different ligand conformers. A $5 \AA$ search radius from center of the pocket, defined by equivalent positions to the center of the pyranose ring found in StGE2 (PDB accession: 4g4j), was utilized and over 1000 docking poses were generated. All other search parameters 
were set to default conditions. The top 300 poses containing the lowest interface delta score were chosen for further analyses.

\section{Additional file}

Additional file 1: Table S1. Percent sequence identity and percent query coverage (in brackets) between all CE15 enzymes used in this study. Sequence identity values for CE15 enzymes within one organism are marked green (O. terrae), magenta (S. linguale) and blue (S. usitatus). The query sequences are presented in the top row.Kinetic parameters of O. terrae, S. linguale, and S. usitatus CE15 enzymes on model. Table S2. Kinetic parameters of O. terrae, S. linguale, and S. usitatus CE15 enzymes on model substrates. Esterase activity with benzyl (Bnz), allyl (Allyl), methyl (Me) esters of glucuronoate (GlCA) and galacturonoate ( $G a \mid A)$ are shown in addition to acetyl esterase activity with 4-nitrophenol acetate ( $p N P$-Ac) and 1,2,3,4-tetra-O-acetyl- $\beta$-D-xylopyranose (TetAcXyl). Table S3. Primers used for cloning CE15 constructs and for qPCR of S. linguale CE15 members. Table S4. Table of crystallographic statistics. Figure S1. Unrooted phylogenetic tree of all members of CE15 (catalytic domains), with Genbank accession numbers as identifiers. Yellow branches represent fungal members, circles indicate biochemically characterized members, and stars represent members with solved structures. Targets of this study are shown using the same color code as in the main text: green for 0 . terrae, red for S. linguale, and blue for S. usitatus. Figure S2. Model substrates used in this study: (A) BnzGlcA, (B) AllylGlcA, (C) MeGlcA, (D) MeGalA, (E) pNP-Ac and (F) TetAcXyl. Figure S3. Effect of pH on BnzGlcA esterase activity for CE15 enzymes from O. terrae (OtCE15 A-D, panels A-D), S. linguale (SICE15 A-C, panels E-G), and S. usitatus (SUCE15 A-C, panels H-J). Mean values of relative activity from duplicate measurements are plotted with standard error of the mean. Figure S4. Structure-based sequence alignment of all CE15 enzymes structurally characterized to date. Similar residues are written in red text while conserved residues are written in white text over a red background. The insertion regions found in the bacterial structures relative to the fungal counterparts are highlighted in yellow. The residues of the canonical catalytic triad are indicated by cyan arrows below the text. The aspartate in MZ0003 proposed to act as the acidic residue of the catalytic triad, in place of the missing canonical glutamate, is indicate by a black arrow below the text. Note that both OtCE15A and SUCE15C also have an aspartate at the same position while additionally having the glutamate of the canonical catalytic triad. Residues hydrogen bonding with 4-O-methyl-glucuronoate in the StGE2 co-crystal structure are indicated by blue arrows above the text. The isoleucine and leucine comprising a hydrophobic patch near the 4-O-methyl substituent in the StGE2 co-crystal structure are indicated by magenta arrows. The phenylalanine conserved in the bacterial structures possibly aiding in positioning in aromatic substituents of the sugar esters is indicated with a grey arrow. The disulfide bridges formed in the fungal structures are indicated above the alignment by numbering in green text. Figure S5. Multiple sequence alignment of characterized glucuronoyl esterases. Similar residues are written in red text while conserved residues are written in white text over a red background. The insertion regions found in the bacterial structures relative to the fungal counterparts are highlighted in yellow. The residues of the conserved catalytic triad are colored cyan. Note that glutamate of the catalytic triad is not conserved in all bacterial esterases and the position of the equivalent acidic residue in MZ0003 is also colored cyan. Arrows indicating significant residues are colored as in Additional file 5: Figure S4. Figure S6. Growth curves of S. linguale when grown with different additives or on different carbon sources. S. linguale did not grow on standard minimal media and an optimized media for bacterial growth was determined experimentally (see methods for formulation). (A) Growth curves of S. linguale in the optimized media without a carbon source (red), with $0.3 \%(\mathrm{w} / \mathrm{v})$ glucose (blue) and in the media containing glucose but in the absence of either trace metals and vitamins (green), sodium phosphate pH 7.5 (magenta), or magnesium sulphate (cyan). (B) Growth of $\mathrm{S}$. linguale in optimized media with $0.3 \%$ of either glucose (blue), xylose (purple), or xylan from corn cob (yellow).

\section{Abbreviations}

GE: glucuronoyl esterase; CE15: carbohydrate esterase 15; LCC: lignin carbohydrate complex; CAZy: carbohydrate active enzyme database; GlcA: glucuronoate/glucuronic acid; GalA: galacturonoate/galacturonic acid; BnzGlcA: benzyl glucuronoate; AllylGIcA: allyl glucuronoate; MeGlcA: methyl glucuronoate; MeGalA: methyl galacturonoate; pNP-Ac: 4-nitrophenol acetate; PDB: protein data bank; IPTG: isopropyl $\beta$-D-1-thiogalactopyranoside.

\section{Authors' contributions}

JAB, SM, LLL, LO, and JL conceived the project. JAB and SM completed the transcriptional analysis, produced, and characterized all of the enzymes, and prepared the manuscript. JAB completed the enzyme cocktail-boosting analysis. RMK, SM, JCP, and LLL solved the structure of the OtCE15A, while the SUCE15C structure was solved by SM, JAB, JCP, and LLL. JL directed the overall study, while $J$, LLL, and LO critically appraised and revised the manuscript. All authors read and approved the final manuscript.

\section{Authors' information}

LLL, RMK, and JCP are members of ISBUC, Integrative Structural Biology at the University of Copenhagen (http://www.isbuc.ku.dk).

\section{Author details}

${ }^{1}$ Wallenberg Wood Science Center, Division of Industrial Biotechnology, Department of Biology and Biological Engineering, Chalmers University of Technology, Gothenburg, Sweden. ${ }^{2}$ Department of Chemistry, University of Copenhagen, Copenhagen, Denmark.

\section{Acknowledgements}

We thank Amanda Sörensen Ristinmaa for assistance in enzyme production and purification.

\section{Competing interests}

The authors declare that they have no competing interests.

\section{Availability of data and materials}

Models of OtCE15A, OtCE15A-Au, SuCE15C, and SuCE15-SeMet have been deposited in the PDB with codes $6 \mathrm{gs} 0,6 \mathrm{grw}, 6 \mathrm{gry}$, and $6 \mathrm{gu} 8$, respectively.

\section{Consent for publication}

Not applicable.

\section{Ethics approval and consent to participate}

Not applicable.

\section{Funding}

The work performed at the Chalmers University of Technology was supported by the Knut and Alice Wallenberg Foundation through the Wallenberg Wood Science Center. Support for collaborative work between the Chalmers University of Technology and the Copenhagen University was provided by the MAX4ESSFUN: Cross Border Science and Society program (Ref. No. CTH-003) and the Novo Nordisk foundation (NNF17OC0027698, Biotechnology-based Synthesis and Production Research).

\section{Publisher's Note}

Springer Nature remains neutral with regard to jurisdictional claims in published maps and institutional affiliations.

Received: 15 May 2018 Accepted: 23 July 2018

Published online: 01 August 2018

\section{References}

1. Watanabe T. Structural studies on the covalent bonds between lignin and carbohydrate in lignin-carbohydrate complexes by selective oxidation of the lignin with 2, 3-dichloro-5, 6-dicyano-l, 4-benzoquinone. Wood Res. 1989;76:59-123.

2. Lombard V, Golaconda Ramulu H, Drula E, Coutinho PM, Henrissat B. The carbohydrate-active enzymes database (CAZy) in 2013. Nucleic Acids Res. 2014:42:D490-5. 
3. Spanikova S, Biely P. Glucuronoyl esterase-novel carbohydrate esterase produced by Schizophyllum commune. FEBS Lett. 2006;580:4597-601.

4. Biely P. Microbial glucuronoyl esterases: 10 years after discovery. Appl Environ Microbiol. 2016;82:7014-8.

5. Agger JW, Busk PK, Pilgaard B, Meyer AS, Lange L. A new functional classification of glucuronoyl esterases by peptide pattern recognition. Front Microbiol. 2017;8:309.

6. Wong DW, Chan VJ, McCormack AA, Hirsch J, Biely P. Functional cloning and expression of the Schizophyllum commune glucuronoyl esterase gene and characterization of the recombinant enzyme. Biotechnol Res Int. 2012;2012:951267.

7. Tsai AY, Canam T, Gorzsas A, Mellerowicz EJ, Campbell MM, Master ER. Constitutive expression of a fungal glucuronoyl esterase in Arabidopsis reveals altered cell wall composition and structure. Plant Biotechnol J. 2012;10:1077-87

8. Duranova M, Hirsch J, Kolenova K, Biely P. Fungal glucuronoyl esterases and substrate uronic acid recognition. Biosci Biotechnol Biochem. 2009;73:2483-7.

9. d'Errico C, Jorgensen JO, Krogh KB, Spodsberg N, Madsen R, Monrad RN. Enzymatic degradation of lignin-carbohydrate complexes (LCCs): model studies using a fungal glucuronoyl esterase from Cerrena unicolor. Biotechnol Bioeng. 2015;112:914-22.

10. Katsimpouras C, Benarouche A, Navarro D, Karpusas M, Dimarogona M, Berrin JG, Christakopoulos P, Topakas E. Enzymatic synthesis of model substrates recognized by glucuronoyl esterases from Podospora anserina and Myceliophthora thermophila. Appl Microbiol Biotechnol. 2014:98:5507-16.

11. Vafiadi C, Topakas E, Biely P, Christakopoulos P. Purification, characterization and mass spectrometric sequencing of a thermophilic glucuronoyl esterase from Sporotrichum thermophile. FEMS Microbiol Lett. 2009;296:178-84

12. Huynh $\mathrm{HH}$, Arioka M. Functional expression and characterization of a glucuronoyl esterase from the fungus Neurospora crassa: identification of novel consensus sequences containing the catalytic triad. J Gen Appl Microbiol. 2016;62:217-24

13. Huttner S, Klaubauf S, de Vries RP, Olsson L. Characterisation of three fungal glucuronoyl esterases on glucuronic acid ester model compounds. Appl Microbiol Biotechnol. 2017;101:5301-11.

14. Topakas E, Moukouli M, Dimarogona M, Vafiadi C, Christakopoulos P. Functional expression of a thermophilic glucuronoyl esterase from Sporotrichum thermophile: identification of the nucleophilic serine. Appl Microbiol Biotechnol. 2010;87:1765-72.

15. Huynh HH, Ishii N, Matsuo I, Arioka M. A novel glucuronoyl esterase from Aspergillus fumigatus-the role of conserved Lys residue in the preference for 4-O-methyl glucuronoyl esters. Appl Microbiol Biotechnol. 2018;102:2191-201.

16. Biely P, Malovikova A, Uhliarikova I, Li XL, Wong DW. Glucuronoyl esterases are active on the polymeric substrate methyl esterified glucuronoxylan. FEBS Lett. 2015;589:2334-9.

17. De Santi C, Willassen NP, Williamson A. Biochemical characterization of a family 15 carbohydrate esterase from a bacterial marine arctic metagenome. PLOS ONE. 2016;11:e0159345.

18. Aurilia V, Martin JC, McCrae SI, Scott KP, Rincon MT, Flint HJ. Three multidomain esterases from the cellulolytic rumen anaerobe Ruminococcus flavefaciens 17 that carry divergent dockerin sequences. Microbiology. 2000;146:1391-7.

19. Arnling Baath J, Giummarella N, Klaubauf S, Lawoko M, Olsson L. A glucuronoyl esterase from Acremonium alcalophilum cleaves native lignin-carbohydrate ester bonds. FEBS Lett. 2016;590:2611-8.

20. d'Errico C, Borjesson J, Ding H, Krogh KB, Spodsberg N, Madsen R, Monrad $\mathrm{RN}$. Improved biomass degradation using fungal glucuronoyl-esteraseshydrolysis of natural corn fiber substrate. J Biotechnol. 2016;219:117-23.

21. Mosbech C, Holck J, Meyer AS, Agger JW. The natural catalytic function of CuGE glucuronoyl esterase in hydrolysis of genuine lignin-carbohydrate complexes from birch. Biotechnol Biofuels. 2018;11:71.

22. Pokkuluri PR, Duke NE, Wood SJ, Cotta MA, Li XL, Biely P, Schiffer M. Structure of the catalytic domain of glucuronoyl esterase Cip2 from Hypocrea jecorina. Proteins. 2011;79:2588-92.

23. Charavgi MD, Dimarogona M, Topakas E, Christakopoulos P, Chrysina ED. The structure of a novel glucuronoyl esterase from Myceliophthora thermophila gives new insights into its role as a potential biocatalyst. Acta Crystallogr D Biol Crystallogr. 2013;69:63-73.

24. De Santi C, Gani OA, Helland R, Williamson A. Structural insight into a CE15 esterase from the marine bacterial metagenome. Sci Rep. 2017;7:17278.

25. Hengstmann U, Chin KJ, Janssen PH, Liesack W. Comparative phylogenetic assignment of environmental sequences of genes encoding $16 \mathrm{~S}$ rRNA and numerically abundant culturable bacteria from an anoxic rice paddy soil. Appl Environ Microbiol. 1999:65:5050-8.

26. Lail K, Sikorski J, Saunders E, Lapidus A, Del Rio TG, Copeland A, Tice H, Cheng JF, Lucas S, Nolan M, et al. Complete genome sequence of Spirosoma linguale type strain (1(T)). Stand Genomic Sci. 2010;2:176-85.

27. Ward NL, Challacombe JF, Janssen PH, Henrissat B, Coutinho PM, Wu M, Xie G, Haft DH, Sait M, Badger J, et al. Three genomes from the phylum Acidobacteria provide insight into the lifestyles of these microorganisms in soils. Appl Environ Microbiol. 2009;75:2046-56.

28. Sunner H, Charavgi MD, Olsson L, Topakas E, Christakopoulos P. Glucuronoyl esterase screening and characterization assays utilizing commercially available benzyl glucuronic acid ester. Molecules. 2015:20:17807-17.

29. Li XL, Spanikova S, de Vries RP, Biely P. Identification of genes encoding microbial glucuronoyl esterases. FEBS Lett. 2007;581:4029-35.

30. Krissinel E, Henrick K. Inference of macromolecular assemblies from crystalline state. J Mol Biol. 2007;372:774-97.

31. da Silva JC, de Oliveira RC, Neto AD, Pimentel VC, dos Santos AD. Extraction, addition and characterization of hemicelluloses from corn cobs to development of paper properties. Proc Mat Sci. 2015;8:793-801.

32. Spanikova S, Polakova M, Joniak D, Hirsch J, Biely P. Synthetic esters recognized by glucuronoyl esterase from Schizophyllum commune. Arch Microbiol. 2007;188:185-9.

33. Larsbrink J, Izumi A, Ibatullin FM, Nakhai A, Gilbert HJ, Davies GJ, Brumer $\mathrm{H}$. Structural and enzymatic characterization of a glycoside hydrolase family 31 alpha-xylosidase from Cellvibrio japonicus involved in xyloglucan saccharification. Biochem J. 2011;436:567-80.

34. Li W, Cowley A, Uludag M, Gur T, McWilliam H, Squizzato S, Park YM, Buso $\mathrm{N}$, Lopez R. The EMBL-EBI bioinformatics web and programmatic tools framework. Nucleic Acids Res. 2015;43:W580-4.

35. Guindon S, Dufayard JF, Lefort V, Anisimova M, Hordijk W, Gascuel O. New algorithms and methods to estimate maximum-likelihood phylogenies: assessing the performance of PhyML 3.0. Syst Biol. 2010;59:307-21.

36. Ellis KJ, Morrison JF. Buffers of constant ionic-strength for studying $\mathrm{pH}$ dependent processes. Methods Enzymol. 1982:87:405-26.

37. Grsic-Rausch S, Rausch T. A coupled spectrophotometric enzyme assay for the determination of pectin methylesterase activity and its inhibition by proteinaceous inhibitors. Anal Biochem. 2004;333:14-8.

38. Verduyn C, Postma E, Scheffers WA, Vandijken JP. Effect of benzoic-acid on metabolic fluxes in yeasts - a continuous-culture study on the regulation of respiration and alcoholic fermentation. Yeast. 1992;8:501-17.

39. Livak KJ, Schmittgen TD. Analysis of relative gene expression data using real-time quantitative PCR and the 2(T)(-Delta Delta C) method. Methods. 2001;25:402-8

40. Gorrec F. The MORPHEUS protein crystallization screen. J Appl Crystallogr. 2009:42:1035-42

41. Kabsch W. XDS. Acta Crystallogr Sect D Biol Crystallogr. 2010;66:125-32.

42. Adams PD, Afonine PV, Bunkoczi G, Chen VB, Davis IW, Echols N, Headd JJ, Hung LW, Kapral GJ, Grosse-Kunstleve RW, et al. PHENIX: a comprehensive Python-based system for macromolecular structure solution. Acta Crystallogr Sect D Biol Crystallogr. 2010;66:213-21.

43. Mccoy AJ, Grosse-Kunstleve RW, Adams PD, Winn MD, Storoni LC, Read RJ. Phaser crystallographic software. J Appl Crystallogr. 2007:40:658-74.

44. Terwilliger TC, Grosse-Kunstleve RW, Afonine PV, Moriarty NW, Zwart PH, Hung LW, Read RJ, Adams PD. Iterative model building, structure refinement and density modification with the PHENIX AutoBuild wizard. Acta Crystallogr Sect D Biol Crystallogr. 2008;64:61-9.

45. Emsley P, Lohkamp B, Scott WG, Cowtan K. Features and development of Coot. Acta Crystallogr Sect D Biol Crystallogr. 2010;66:486-501.

46. Afonine PV, Grosse-Kunstleve RW, Echols N, Headd JJ, Moriarty NW, Mustyakimov M, Terwilliger TC, Urzhumtsev A, Zwart PH, Adams PD. Towards automated crystallographic structure refinement with phenix.refine. Acta Crystallogr Sect D Biol Crystallogr. 2012;68:352-67. 
47. Zheng H, Cooper DR, Porebski PJ, Shabalin IG, Handing KB, Minor W. CheckMyMetal: a macromolecular metal-binding validation tool. Acta Crystallogr Sect D Struct Biol. 2017;73:223-33.

48. Lovell SC, Davis IW, Arendall WB 3rd, de Bakker PI, Word JM, Prisant MG, Richardson JS, Richardson DC. Structure validation by Calpha geometry: phi, psi and Cbeta deviation. Proteins. 2003;50:437-50.

49. Sievers F, Wilm A, Dineen D, Gibson TJ, Karplus K, Li W, Lopez R, McWilliam $H$, Remmert M, Soding J, et al. Fast, scalable generation of high-quality protein multiple sequence alignments using Clustal Omega. Mol Syst Biol. 2011;7:539.

50. Holm L, Laakso LM. Dali server update. Nucleic Acids Res. 2016:44:W351-5

51. Robert $X$, Gouet P. Deciphering key features in protein structures with the new ENDscript server. Nucleic Acids Res. 2014;42:W320-4.
52. DeLuca S, Khar K, Meiler J. Fully flexible docking of medium sized ligand libraries with RosettaLigand. PLoS ONE. 2015;10:e0132508.

53. Combs SA, Deluca SL, Deluca SH, Lemmon GH, Nannemann DP, Nguyen ED, Willis JR, Sheehan JH, Meiler J. Small-molecule ligand docking into comparative models with Rosetta. Nat Protoc. 2013;8:1277-98.

54. Kothiwale S, Mendenhall JL, Meiler J. BCL:Conf: small molecule conformational sampling using a knowledge based rotamer library. J Cheminform. 2015;7:47.

55. Lyskov S, Chou FC, Conchuir SO, Der BS, Drew K, Kuroda D, Xu J, Weitzner BD, Renfrew PD, Sripakdeevong P, et al. Serverification of molecular modeling applications: the Rosetta Online Server that Includes Everyone (ROSIE). PLOS ONE. 2013;8:e63906.
Ready to submit your research? Choose BMC and benefit from:

- fast, convenient online submission

- thorough peer review by experienced researchers in your field

- rapid publication on acceptance

- support for research data, including large and complex data types

- gold Open Access which fosters wider collaboration and increased citations

- maximum visibility for your research: over $100 \mathrm{M}$ website views per year

At BMC, research is always in progress.

Learn more biomedcentral.com/submissions 